Court and the UN Security Council makes it possible to try cases of international crimes and take effective measures to counter such crimes. As a key component of the International criminal justice system, the International criminal Court is one of the most significant institutions of international criminal law, which is constantly developing and to a certain extent affects the patterns in the development of mechanisms for the investigation of international crimes and the protection of human rights at the international and national levels.

Key words: aggression, international crime, international criminal justice, Rome Statute, International criminal court.

DOI: 10.36695/2219-5521.3.2020.70

удк 349.6(100)

\title{
O.О. ХАРЧУК
}

Олександр Олександрович Харчук, кандидат юридичних наук, доцент*

ORCID: 0000-0002-0552-8205

\section{ЕКОНОМІЧНА СКЛАДОВА РЕАЛІЗАЦІЇ СТАЛОГО РОЗВИТКУ}

Постановка проблеми. Питання сталого розвитку знаходяться на порядку денному міжнародного співтовариства. До таких питань можна віднести соціальні, економічні та екологічні. Саме ці питання ключові у обговорені. Держави невпинно шукають шляхи подолання бідності, вирішення проблем клімату і пошуку нових, більш ефективних шляхів економічної співпраці. Водночас перебіг подій на міжнародній арені засвідчує складність пошуку спільного знаменника. На перешкоді стають власні інтереси, небажання обтяжувати себе додатковими зобов'язаннями, відсутність єднаючого стрижня у баченні кінцевого результату. Незважаючи на декларування «справедливості для всіх поколінь» у задоволенні сучасних потреб людства не враховується благополуччя майбутніх поколінь. Світове співтовариство дедалі частіше стикається із гострими політичними, соціальними та економічними ситуаціями. За цих обставин виникла потреба посилення ролі міжнародного управління процесом розвитку, а не лише здійсненням міжнародної співпраці. Останній потребує, щоб держави відповідали критеріям такого розвитку. Один із ключових критеріїв - це виважена економічна, соціальна та економічна політика; із подальшим втіленням на національних рівнях. Остання має бути логічним продовженням узгоджених дій світової спільноти. Лише у поєднанні цих двох рівнів можна досягти виявлення суперечностей з їх подальшим подоланням, тобто започаткуванням системи глобального керівництва такими процесами. Звісно, досягненню глобального рівня має передувати пошук консенсусу на регіональному, багатосторонньому, а подекуди й двосторонньому, і роль міжнародних організацій у цьому процесі повинна бути провідною.

Фактично сталий розвиток можна звести, зокрема, до таких ключових напрямів реалізації: економічний розвиток, придатне для проживання середовище, соціальний прогрес і відповідальність за природнє середовище. Звісно, кожен із цих напрямів можна поділити на цілі із більш конкретними сферами діяльності: інновації, управління ризиками, зайнятість населення і підвищення його кваліфікації, дотримання прав людини, покращення рівня охорони здоров'я, збереження чистого повітря і води, екологічне правосуддя тощо.

Аналіз останніх досліджень і публікацій. Питання сталого розвитку становить значний науковий інтерес. Дослідженню тих чи інших аспектів цього явища присвячено праці таких українських учених, як Б.В. Бабіна, В.А. Василенка, I.І. Лукашука, Н.Д. Янчук.

Зарубіжними вченими також немало уваги було приділено праву на розвиток. Так, це питання досліджувалося М. Беджауі, К. Васакою, Л.М. Ентіним, С.В. Масловою, Ю.М. Колосовим, О. Ріверою, Г.І. Тункіним та ін.

Формулювання мети статті. Виходячи із вищевикладеного, мета статті полягає у розкритті ролі економічної складової в реалізації сталого розвитку.

Виклад основного матеріалу. Актуальність питання розвитку віддзеркалюють міжнародні відносини. Сталий розвиток бере свій початок із концепції нового міжнародного економічного поряду. Остання виникла у шістдесятих роках XX ст. Тоді в основу НМЕП було покладено несправедливість економічної системи для країн, що розвиваються, зумовлені зовнішньою заборгованістю, наслідками діяльності транснаціональних корпорацій, відсутністю технологій, нездатністю виробляти готову продукцію. Але реалізація НМЕП у правовій площині закінчилася прийняттям Принципів міжнародних торговельних відносин і торговельної політики, що сприяють розвитку, Декларації і Програми дій зі встановлення нового міжнародного економічного порядку, Хартії економічних прав і обов’язків держав. Водночас уся ця правова основа носила характер «м'якого права». Як наслідок, було створено низку міжнародних механізмів допомоги країнам, що розвиваються. Так, було започатковано механізм міжнародної фінансової допомоги, Фонд компенсаційного фінансування, програму субсидій для країн Африки, Карибського басейну та Тихого океану, Фонд для боротьбі 3 бідністю і забезпечення зростання, Фонд МВФ для надання допомоги у випадку зовнішніх потрясінь, фонд

(C) О.О. Харчук, 2020

* Oleksandr Kharchuk, Ph.D. in Law, Associate Professor 
МВФ для коректування платіжних балансів, механізм інтеграції торгівлі (при МВФ), Механізм митних преференцій, механізм регулювання торгівлі сировинними товарами, механізм регулювання боргів країн, що розвиваються 1 . Фактично, в подальшому держави зіткнулися із посиленням ролі міжнародних інституційних утворень у поєднанні із тенденцією до зростання опору прийняття обов'язкових рішень з боку розвинених держав. Виникнення поняття «сталого розвитку» пов'язують із діяльністю Міжнародної комісії з навколишнього середовища, створеною в 1983 р. під егідою ООН. Комісію очолювала Гарлем Брутландт, і тому іiі зазвичай називають «Комісією Брутландт». Діяльність комісії була спрямована на підготовку доповіді в контексті Всесвітньої стратегії охорони природи. Водночас сталий розвиток не міг обмежитися діями виключно у природоохоронній сфері i, зумовлював потребу використання комплексного підходу в проведенні змін розвитку світової спільноти. Держави зіткнулися із необхідністю поєднання екологічного фактору з економічним та соціальним. Фактично початок 1990-х рр. ознаменував початок становлення концепції сталого розвитку.

До ядра ідеї сталого розвитку входить визнання необхідності сталого розвитку суспільств, здатних забезпечувати свободу і гідне життя своїм громадянам. Основні смисли та імперативи ідеї полягають у свободі, рівності, солідарності, верховенстві права, людській гідності, толерантності, дотриманні загальнолюдських цінностей. Зазначене виступає комплементарними настановами, що посилює їх впливовість та значущість як регуляторів сталого розвитку.

Станом на сьогодні фактично світ підходить до межі того, що не втілення сталого розвитку буде залежати від потуг світової спільноти, а вплив чинників соціального, економічного та кліматичного характеру зумовлюватиме напрями розвитку міждержавних відносин загалом і державних політик на національних рівнях зокрема. Фактично подальший економічний розвиток людства може стати причиною виснаження природних ресурсів та згубного спливу на навколишне середовище. Намагання розвинених країн дистанціюватися від реалізації стратегії сталого розвитку не сприяє виникненню атмосфери довіри та порозуміння.

Водночас право розвитку покладає на суб'єктів міжнародних економічних відносин обов'язок безпосередньо не лише брати участь у цьому процесі, а й не перешкоджати йому, створювати сприятливі умови розвитку. Країни мають право самостійно визначати шляхи свого розвитку і забезпечувати його здійснення. Своєю чергою, проведення економічного розвитку передбачає необхідність впровадження процесів індустріалізації і модернізації виробничих потужностей, диверсифікації торговельних відносин. Важливим елементом здійснення права на розвиток виступає розроблення дієвих механізмів міжнародної співпраці². Разом iз тим міжнародним економічним відносинам характерні: поглиблення інтернаціоналізації, зростання рівня взаємозалежності учасників, виникнення якісно нових засобів та форм взаємодії суб'єктів, посиленням явищ протекціонізму власних економічних інтересів, наявність гострих протиріч між політичною та правовою складовою у міждержавних відносинах, небажання держав перетворювати норми «м'якого права» на загальнообов'язкові.

Водночас міжнародне право нерозривно пов'язане із питаннями сталого розвитку, адже забезпечення безпеки, як одного з провідних загальновизнаних принципів міжнародного прав, неможливе без дотримання концепції сталого розвитку. Втілення останньої визначає завдання та окреслює проблеми, які підлягають вирішенню. Концепція сталого розвитку фактично перетворюється на глобальний напрям руху держав, і від усвідомлення необхідності їі дотримання залежить спільне майбутнє.

Інституційна складова права сталого розвитку.

Право на розвиток не можна собі уявити без інституціональних механізмів міжнародного економічного права. Одним із них виступає Конференція ООН з торгівлі і розвитку (далі - ЮНКТАД). Вона здійснює діяльність, покликану допомогти країнам, що розвиваються, інтегруватися в глобальну економічну систему і виступає другою за значущістю міжнародною організацією після Світової Організації Торгівлі (далі (COT)3 ${ }^{3}$ І Іншим таким міжнародним механізмом є Організація Об'єднаних Націй з промислового розвитку (далі - ЮНІДО), яка також присвячує увагу розробці цього питання. Достатньо згадати хоча б той факт, що 2-6 грудня 2013 р. відбулася XV сесія Генеральної конференції ЮНІДО, робота якої була присвячена Лімській Декларації як засобу досягнення загального і сталого промислового розвитку. За результатами обговорення було прийнято Резолюцію GC.15/Res. 1, у п. 2 якої зазначено, що рушійною силою розвитку виступає індустріалізація, водночас окремо наголошується на необхідності промислового розвитку 3 метою досягнення економічного зростання 4 .

Питанню розвитку приділяють увагу й інші міжнародні організації. Так, на європейському континенті функціонує Організація економічного співробітництва та розвитку (далі - ОЕСР), яка в своїй діяльності охоплює не лише країни Європи, а й залучає до співпраці країни Азійського та Американського континентів, координуючи їх роботу у сфері розвитку.

Світова організація торгівлі, яка прийшла на зміну ГАТТ, також не стоїть осторонь проблем розвитку. Так, СОТ підтвердила систему загальних преференцій, на якій базуються торговельні відносини між ЄС та значною кількістю країн, що розвиваються.

Зрозуміло, що діяльність інституційних установ на глобальному, регіональному і субрегіональному рівнях сприяє розвитку партнерських відносин на міждержавному рівні з метою досягнення розвитку. Співпраця держав на інституційному рівні впливає на формування сучасного міжнародного економічного порядку, прискорює створення важливих концептуальних положень правового, економічного і політичного характеру та сприяє загальносвітовому розвитку. 
Своєю чергою, проведення економічного розвитку передбачає необхідність впровадження процесів індустріалізації і модернізації виробничих потужностей, диверсифікації торговельних відносин. Важливим елементом здійснення права на розвиток виступає розроблення дієвих механізмів міжнародної співпраці. Перетворення в цьому напрямі потребують скоординованості дій, взаємної відповідальності й звітності, заінтересованості та ефективності. Саме посилення прозорості і підзвітності у використанні допомоги на розвиток сприятиме створенню ефективних і взаємовигідних партнерських відносин у цій сфері.

Зрозуміло, що діяльність інституційних установ на глобальному і регіональному рівнях сприяє розвитку партнерських відносин на міждержавному рівні з метою досягнення розвитку. Співпраця держав на інституційному рівні впливає на формування сучасного міжнародного економічного порядку, прискорює формування важливих концептуальних положень правового, економічного і політичного характеру та сприяє загальносвітовому розвитку. Водночас процес відбувається непросто. Тут на перешкоді стають фактори, що зумовлюють досягнення у сфері сталого розвитку пропорційно рівню міжнародної співпраці та довіри.

Виклики сталому розвитку:

- держава має відповідати вимогам сталого розвитку;

- держави мають бути готові якщо не системного глобального управління, то, принаймні, до регіонального чи багатостороннього;

- держави мають дійсно навчитися узгоджувати свої дії;

- держави повинні уникати проявів, спрямованих на дестабілізацію та не сприяти встановленню сталої нерозвиненості окремих держав чи потуранню цьому процесу;

- у світі відчувається поступове виникнення ресурсного голоду;

- слід встановити межі «гуманітарних інтервенцій» у контексті реакції держав на кризові явища у інших учасників міждержавних відносин;

- все відчутнішим стає неповноцінне залучення міжнародних інституцій;

- парадигма досягнення сталого розвитку потребує реформування інституційного механізму, набуття ним рис гнучкості та відповідності потребам часу;

- вплив кризових екологічних явищ стає дедалі відчутнішим;

- рівень соціальної нерівності поглиблюється, що призводить до виникнення явищ, спрямованих на спроби досягнути загального світосприйняття на окремих началах (напр. ІДІЛ) та протиставленню цього іншій частині світу;

- держави використовують міжнародні відносини для реалізації наступальних стратегій, що базуються на засадах інформаційно-психологічної боротьби;

- нормою сьогодення стає вихід із багатосторонніх угод чи ведення торговельних війн.

Фактично, без переосмислення ідеї розвитку і переорієнтації держав із показників зростання як кількісних на показники розвитку як якісних, вочевидь, не можна сьогодні говорити про прогрес у цьому напрямі. Тому питання екології, клімату, соціальної нерівності - невід'ємна складова не лише міжнародно-правового рівня, а й національного. Новою парадигмою розвитку міжнародних відносин має стати розвиток від економічного зростання до сталого у широкому сенсі.

На сьогодні лунають заклики до держав реалізовувати подальший розвиток міжнародних відносин, підпорядковуючи його можливому переходу до системи глобального управління 5 . Водночас наявні суперечності навряд чи зроблять цей шлях здійсненним у найближчому майбутньому. Швидше реалізація колективних цілей на регіональному рівні може стати більш здійсненною, ніж бажання стати елементом системи глобального управління. Держави, як і раніше, незважаючи на декларовані цілі, вдаються до використання як правових, так і політичних важелів. Наприклад, розвинені країни намагаються перекласти значну частину відповідальності на країни, що розвиваються. Так, розвинені країни невпинно працюють над енергоефективністю, комп'ютеризацією, екологічними технологіями, водночас не забезпечуючи до своїх здобутків рівного доступу. Це призводить до посилення нерівності, оскільки ставить країни, що розвиваються, перед вибором: або витратами на отримання технологій, або реінвестуванням у власну економіку. Тому напрацювання і реалізація міжнародних програм у межах стратегій сталого розвитку дає змогу отримати більшу віддачу саме розвиненим державам. Останні, здобуваючи успіхи, отримують прибутки від продажу технологій іншим та посилюють таким чином свої позиції на міжнародній арені. Це незворотньо призведе до виникнення на порядку денному питання про роль та статус окремих держав у вирішенні проблем усього людства.

Україна не стоїть осторонь світових процесів. Водночас розвиток міжнародної співпраці нашої держави доволі строкатий. Питання співпраці у контексті сталого розвитку значною мірою гальмує, незважаючи на участь нашої держави у багатьох міжнародних ініціативах. Так, напрацювання України в питанні сталого розвитку значною мірою потерпають від:

- відсутності капіталовкладень;

- донедавна відсутності діджиталізації;

- суцільно негативного досвіду у відносинах інвестора і держави;

- непрогнозованості державної політики;

- неспроможності виробляти готову конкурентоспроможну продукцію, натомість експорт сировини;

- системного ігнорування екологічних загроз;

- посилення соціально-економічного розшарування суспільства;

- відсутності глибоких і послідовних системних перетворень та нездатності протистояти світовим викликам. 
В Україні діють регіональні агенції зі сталого розвитку та Громадське об’єднання «Всеукраїнська агенція інвестицій та сталого розвитку». Водночас окремої державної установи з цього питання немає. Реалізації сталого розвитку в Україні притаманна декларативність та галузева розпорошеність. Відсутність керівного центру нівелює визначену Указом Президента України від 30 вересня 2019 р. № 722/2019, державну політику у сфері впровадження сталого розвитку. Тобто відсутність дієвої системи моніторингу реалізації Цілей сталого розвитку України засвідчує відсутність розроблення проєктів прогнозних і програмних документів, проєктів нормативно-правових актів з метою забезпечення збалансованості економічного, соціального та екологічного вимірів сталого розвитку нашої країни.

Висновки. Отже, сталий розвиток потерпає від відсутності єдиної нормативно-правової бази, яка б дозволила визначити, що можна вважати загальновизнаними принципами і нормами, адже саме з їх допомогою можна було б усунути прогалини в положеннях міжнародних договорів. Праву сталого розвитку притаманна розгалуженість секторальних нормативно-правових положень. Відсутність єдиного підходу в розумінні принципів сталого розвитку призводить до складнощів у розумінні керівних засад реалізації такого розвитку з позицій змісту. Реалізація сталого розвитку на національних рівнях являє собою непросте завдання у зв'язку із розмитістю національних законодавств, недостатністю фінансування та відсутністю належного інституційного потенціалу. Важливим елементом здійснення права на розвиток виступає розроблення дієвих механізмів міжнародної співпраці. Перетворення в цьому напрямі потребують координованості, взаємної відповідальності й звітності, заінтересованості та ефективності. Саме посилення прозорості та підзвітності у використанні допомоги на розвиток сприятиме створенню ефективних і взаємовигідних партнерських відносин у цій сфері, усуненню деструктивної різновекторності. Водночас світ намагається прогнозувати майбутне, а Україна існує в умовах малої прогнозованості. Українське суспільство оглядається у своє минуле i не готується до викликів не лише майбутнього, а й сьогодення.

${ }^{1}$ Курс международного права : учебник / В.Л. Толстых. Москва: Волтерс Клувер, 2009. С. 992-995.

2 Aktualne problem prawa Polski i Urainy / pod redakcja: Anddrzeja Szmyta, Jurija Boszyckiego, Jacuba Steliny, Wiaczeslawa Iwanowa. Gdansk: Wydawnitctwo Uniwersytetu Gdanskiego. 2018. P. 501.

3 Дюмулен И.И. Конференции ООН по торговле и развитию (ЮНКТАД) 50 лет. Российский внешнеэкономический вестник. 2014. № 8. С. 16-17.

4 Лимская декларация: Путь к достижению всеохватывающего промышленного развития: резолюция XV сессии Генеральной конференции ЮНИДО GC.15/Res. 1. URL: www.unido.org/fileadmin/user.../Lima_Declaration_RU_web.pdf

5 Малеев Ю.Н. Международное управление устойчивым развитием: пределы необходимого и возможного. Московский журнал международного права. 2015. № 4. С. 63.

\section{Резюме}

Харчук О.О. Економічна складова реалізації концепції сталого розвитку.

У статті розглянуто проблему реалізації права на розвиток в міжнародному економічному праві в контексті розвитку міжнародного співробітництва. Розглянуто нормативну складову права на розвиток. Проаналізовано зв'язок права на розвиток з системою принципів міжнародного економічного права. Визначено нормативне закріплення елементів права на розвиток в міжнародно-правових актах. Показано застосування права на розвиток в практиці міжнародних організацій. Також у статті розглянуто виклики сьогодення сталому розвитку.

Ключові слова: право на розвиток, принцип, міжнародне економічне право, міжнародні економічні відносини, міжнародне співробітництво, міжнародні організації.

\section{Резюме}

Харчук А.А. Экономическая составляющая реализации концепции устойчивого развития.

В статье рассмотрено проблему реализации права на развитие в международном экономическом праве в контексте развития международного сотрудничества. Рассмотрена нормативная составляющая права на развитие. Проанализирована связь права на развитие с системой принципов международного экономического права. Определено нормативное закрепление элементов права на развитие в международно-правовых актах. Показано применение права на развитие в практике международных организаций. Также в статье рассмотрены вызовы современному устойчивому развитию.

Ключевые слова: право на развитие, принцип, международное экономическое право, международные экономические отношения, международное сотрудничество, международные организации.

\section{Summary}

Oleksandr Kharchuk. Economic component of the sustainable development concept.

The article deals with the problem of the realization of the right to development in international economic law in the context of the development of international cooperation. The normative component of the right to development is considered. The relationship between the right to development and the system of principles of international economic law is analyzed.

The normative fixing of the elements of the right to development in international legal instruments is defined. The application of the right to development in the practice of international organizations is shown. The article also discusses the challenges of today's sustainable development.

Sustainable development is based on three main elements: environmental, economic and social equality. The right to development can't be imagined without the institutional mechanisms of international economic law. It is clear that the activities of institutional insti- 
tutions at the global, regional and subregional levels contribute to the development of partnerships at the interstate level in order to achieve development. Cooperation of states at the institutional level influences the formation of the modern international economic order. Implementing sustainable development at the national level is a difficult task due to the vagueness of national legislation, lack of funding and lack of adequate institutional capacity. An important element in exercising the right to development is the development of effective mechanisms for international cooperation. Transformations in this direction require coordination, mutual responsibility and accountability, interest and efficiency. It is clear that the activities of international institutions at the global, regional and subregional levels promote the development of partner relations at the interstate level in order to achieve development. Cooperation of states at the institutional level affects the formation of modern international economic order, accelerates the formation of important conceptual provisions of a legal, economic and political nature and promotes global development. Transformation in this direction requires coordination of action, mutual accountability and reporting, interest and effectiveness. The enhancement of transparency and accountability in the use of development provides assistance in creation of effective and mutually beneficial partnerships in this area.

Key words: the right to development, the principle, international economic law, international economic relations, international cooperation, international organizations.

DOI: 10.36695/2219-5521.3.2020.71

УДК 341.1 .8

\section{О.О. ЗАДОРОЖНІЙ}

Олександр Олександрович Задорожній, аспірант Інституту міжнародних відносин Київського національного університету імені Тараса Шевченка*

ORCID: 0000-0002-9770-894X

\section{ПРИВАТНІ КОСМІЧНІ ПОЛЬОТИ: ПРАВОВЕ РЕГУЛЮВАННЯ В США}

Постановка проблеми. Поява попиту на космічні подорожі, виникнення комерційних підприємств та туристичних агенцій у сфері космічної індустрії, розробка транспортних засобів, призначених винятково для перевезення туристів у космос - усе це свідчить про те, що космос незабаром може перетворитися з об'єкта наукового дослідження на звичайну дестинацію. Тому на сьогодні правове регулювання приватних космічних польотів $є$ перспективним питанням з огляду на те, що подібного законодавства в Україні нема. Ми звертаємося до аналізу законодавства Сполучених Штатів Америки, щоб оцінити, який масив нормативно-правового врегулювання нам доведеться опанувати, якщо забажаємо розвивати приватні космічні польоти й у себе.

Аналіз останніх досліджень і публікацій. Теоретичні засади дослідження приватних космічних польотів розглядалися автором на базі опрацювання праць науковців у галузі загального міжнародного права, міжнародного та національного космічного права, інших галузей права, таких як: І.П. Андрушко, Л.П. Ануфрієва, О.В. Бєглий, К.А. Бекяшев, У. Больман, М. Вільямс, Д. Волтер, Д. Габрінович, О.М. Григоров, В.Н. Денисов, Р. Джаху, Г.П. Жуков, О.П. Каменецька, Ю.М. Колосов, В.П. Кононенко, Е.С. Крівчікова, К. Крістол, П. Ларсен, Ф. Ляйл, Н.Р. Малишева, Дж. Пелтон, Дж. Сміс, І. Сурбес-Вержер, С. Фріланд, Н. Хедман, Ш. Хобе, Б. Шмідт-Тедд, О.В. Яковенко та ін.

Формулювання мети статті. Основною метою статті є розгляд законодавства Сполучених Штатів Америки як модельного в сфері регулювання приватних космічних польотів.

Виклад основного матеріалу. Приватний космічний політ - це космічний політ або розвиток технології космічних польотів, який проводиться та оплачується суб'єктом господарювання, відмінним від державного органу. Також дане поняття можна охарактеризувати як комерційну космічну діяльність.

У Національній космічній політиці Сполучених Штатів Америки, опублікованій 28 червня 2010 p., президент США Барак Обама визначив «комерційну космічну діяльність» таким чином:

Термін «комерційний» для цілей цієї політики стосується космічних товарів, послуг або видів діяльності, що надаються підприємствами приватного сектору, які несуть розумну частину інвестиційного ризику та відповідають за свою діяльність, працюють відповідно до типових ринкових принципів, стимулюють контроль за витратами та оптимізують рентабельність інвестицій і мають правоздатність пропонувати ці товари чи послуги існуючим або потенційним неурядовим споживачам ${ }^{1}$.

Залежно від мети приватні космічні польоти поділяються на польоти з метою перевезення вантажів та польоти в рамках космічного туризму.

Щодо польотів 3 метою перевезення вантажів, то у перші десятиліття космічної ери урядові космічні агенції США та Радянського Союзу стали піонерами космічної техніки у співпраці з афілійованими конструкторськими бюро СРСР та приватними компаніями США, повністю фінансуючи як розвиток нових космічних польотних технологій, так і експлуатаційні витрати на космічні польоти.

(C) О.О. Задорожній, 2020

* Oleksandr Zadorozhny, Postgraduate student of the Institute of International Relations Taras Shevchenko National University of Kyiv 